\title{
An Analysis of Cybercrime Scenario in Pune
}

\author{
Mayank R. Kothawade \\ Research Scholar, North Maharashtra University, \\ Jalgaon (MH), India
}

\author{
Preeti Agarwal, PhD \\ Director, G.H. Raisoni Institute of Business \\ Management, Jalgaon (MH), India
}

\begin{abstract}
IT plays crucial role in personal lives and business. Technological innovation is an evolutionary process. Personally the researcher also finds IT to be interesting, intriguing and powerful, at a same time challenging, confusing and risky. As well as there are inherent challenges to the field of IT Security. Pune, the IT hub is also suffering due to cybercrimes and variety of security issues. Obviously better and smarter defensive systems will help, though it must also be noted that in the cyber world, hackers always tend to keep a step or two ahead of large outfits.
\end{abstract}

Being a source of large infrastructural facilities and environmental factors Pune city continuously growing. Including colleges, institutes offering various courses and corporate sector from manufacturing industries to IT sector are giving the first preference to Pune city. In today's internet world almost all are connected globally. This global connectivity now emerging as a biggest challenge for the law enforcers to secure the society from cyberattacks. In this research paper researchers have share the cybercrime scenario along with different types of cybercrimes and their analysis based on IT act and IPC.

\section{Keywords}

IT act, IPC, Cybercrimes, Cybercrime analysis, Cybercrime classification, Pune

\section{INTRODUCTION}

The term 'cyber' is derived from the word 'cybernetics' which means science of communication and control over machine and man. Cyberspace is the new horizon which is controlled by machine for information and communication between human beings across the world. Therefore, crimes committed in cyberspace are to be treated as cybercrimes. In wider sense, cybercrime is a crime on the Internet which includes hacking, terrorism, fraud, gambling, cyber stalking, cyber theft, cyber pornography, flowing of viruses etc. Cybercrime means unlawful act wherein the computer is either a tool or a target or both ${ }^{1}$. Any use of a computer as an instrument to further illegal ends, such as committing fraud, trafficking in child pornography and intellectual property, stealing identities or violating privacy ${ }^{2}$. Cybercrime is defined as a crime in which a computer is the object of the crime (hacking, phishing, spamming etc.) or is used as a tool to commit an offense. Cybercrime is also known as crime against an organization or an individual in which the perpetrator of the crime uses a computer or any computer enabled technology for all or part of the time ${ }^{3}$.

Cybercrime is evolving as a serious threat. Worldwide governments, police departments and intelligence units have started to react. Initiatives to control cross border cyber threats are taking shape. Indian police has initiated special cyber cells across the country and have started educating the personnel ${ }^{4}$. Introducing the cyber law in India helps to reduce the cybercrimes to some extent, through cyber law many people get arrested and they are now behind the bars but the frequency of incidences leaves significant impact on the society. Cybercrime security system requirements are continuously increasing everyday as crimes rate is swelling ${ }^{5}$.

\section{OBJECTIVES}

1. To identify the existence of cybercrimes in Pune.

2. To know awareness on various types of cybercrimes amongst internet users in Pune.

3. To analyze the cybercrime scenario in Pune.

\section{METHODOLOGY}

Primary data of 510 internet users has been collected from the four different zones of Pune on the basis of number of internet users in Pune according to IMEI report- $2011^{6}$. Sample size selection was made on the basis of 'Morgan' table ${ }^{7}$ using multistage stratified random sampling ${ }^{8}$. Secondary data was collected from the website of National Crime Record Bureau. Data analysis has been performed using SPSS21 and Microsoft excel.

\section{CYBERCRIME CLASSIFICATION}

Cybercrimes on the basis of nature and divergent types of attacks are classified into following main categories ${ }^{9}$. Knowingly or unknowingly internet users becoming the victims of different types cyber-attacks. These attacks may vary in nature and their impact moreover it difficult to understand these attacks.

Crimes against individual- These are the crimes against person, against property of an individual are included. Against persons include harassment through e-mail, cyber stalking, dissemination of obscene material on the Internet, defamation, hacking / cracking and by indecent exposure. Cybercrimes against property of an individual include computer vandalism, transmitting virus, Internet intrusion, unauthorized control over computer system and hacking / cracking etc ${ }^{9,10}$.

Crimes against organizations- Includes crimes against government, private firm, company, group of individual etc. These crimes can be made by hacking and cracking, by possession of unauthorized information and through cyber terrorism against the government organization. Distribution of pirated softwares also covered under these attacks ${ }^{9}, 10$.

Crimes against property- Involve credit card frauds, crimes related to intellectual property and internet time theft etc ${ }^{9}, 10$.

Crimes against society- These crimes not only affect individual or any organization but the society at large. They include Pornography (especially child pornography), polluting the youth through indecent exposure and trafficking etc ${ }^{10}$.

\section{Cybercrimes emanating from UseNet newsgroups-}

These attacks may carry very offensive, harmful, inaccurate or otherwise inappropriate material, or in some cases posting have been mislabeled or are deceptive in another way ${ }^{10}$. 


\section{CYBERCRIME EXISTENCE IN PUNE}

To identify cybercrime existence following questions were asked to the internet users in Pune.

Q1.Have you faced any problem on cybersecurity or internet/online security? Response options ( $1=$ Yes, $2=\mathrm{No})$

Table 1: Problems faced on cybersecurity or internet/online security

\begin{tabular}{|cc|c|c|c|c|}
\hline & Frequency & Percent & $\begin{array}{c}\text { Valid } \\
\text { Percent }\end{array}$ & $\begin{array}{c}\text { Cumulative } \\
\text { Percent }\end{array}$ \\
\hline Ves & 358 & 70.2 & 70.2 & 70.2 \\
Valid No & 152 & 29.8 & 29.8 & 100.0 \\
& Total & $\mathbf{5 1 0}$ & $\mathbf{1 0 0 . 0}$ & $\mathbf{1 0 0 . 0}$ & \\
\hline
\end{tabular}

Graph 1: Problems faced on cybersecurity or internet/ online security

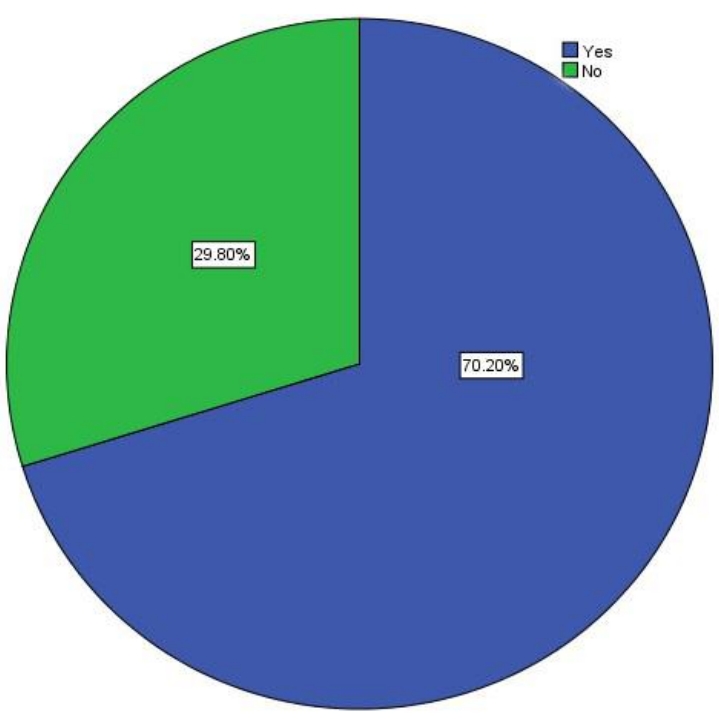

From the above frequency distribution table it can be seen that out of 510 respondents $30 \%$ respondents never faced any problem and $70 \%$ respondents faced problems on cybersecurity or internet/online security. Hence most of the internet users faced cybersecurity or internet/online security problems.

Q2. If yes, what was the nature of problem faced? (Select all that applicable)

Table 2: Nature of problem(s) faced

\begin{tabular}{|l|c|c|c|}
\hline & \multicolumn{2}{|c|}{ Responses } & Percent \\
\cline { 2 - 3 } & $\mathrm{N}$ & Percent & $\begin{array}{c}\text { of } \\
\text { Cases }\end{array}$ \\
\hline Virus Attack & 427 & $31.1 \%$ & $83.7 \%$ \\
Trojan horse & 145 & $10.6 \%$ & $28.4 \%$ \\
Spamming & 58 & $4.2 \%$ & $11.4 \%$ \\
Phishing & 68 & $4.9 \%$ & $13.3 \%$ \\
Online frauds & 95 & $6.9 \%$ & $18.6 \%$ \\
Unauthorized access to devices & 20 & $1.5 \%$ & $3.9 \%$ \\
\hline Intellectual Property crimes & 1 & $0.1 \%$ & $0.2 \%$ \\
Email Scam / Email Spoofing & 10 & $0.7 \%$ & $2.0 \%$ \\
Credit Card Frauds & 32 & $2.3 \%$ & $6.3 \%$ \\
Cyber Defamation & 1 & $0.1 \%$ & $0.2 \%$ \\
Software Piracy & 7 & $0.5 \%$ & $1.4 \%$ \\
Internet Time Theft & 26 & $1.9 \%$ & $5.1 \%$
\end{tabular}

\begin{tabular}{|l|c|c|c|} 
Computer Sabotage & 13 & $0.9 \%$ & $2.5 \%$ \\
Password Sniffing & 18 & $1.3 \%$ & $3.5 \%$ \\
Identity Theft & 3 & $0.2 \%$ & $0.6 \%$ \\
DOS/DDOS attacks & 2 & $0.1 \%$ & $0.4 \%$ \\
Pornographic Offences & 9 & $0.7 \%$ & $1.8 \%$ \\
Cross Site Scripting & 19 & $1.4 \%$ & $3.7 \%$ \\
Salami Attacks/Techniques & 7 & $0.5 \%$ & $1.4 \%$ \\
Cyberstalking/Harassment & 10 & $0.7 \%$ & $2.0 \%$ \\
E-mail bombing/Mail bombs & 26 & $1.9 \%$ & $5.1 \%$ \\
Computer Network Intrusion & 11 & $0.8 \%$ & $2.2 \%$ \\
Shortened and Hidden Link & 9 & $0.7 \%$ & $1.8 \%$ \\
Webjacking/Clickjacking/ & 261 & $19.0 \%$ & $51.2 \%$ \\
Pop-Up & 96 & $7.0 \%$ & $18.8 \%$ \\
Others & $\mathbf{1 3 7 4}$ & $\mathbf{1 0 0 . 0 \%}$ & $\mathbf{2 6 9 . 4 \%}$ \\
\hline Total & \multicolumn{3}{|l}{}
\end{tabular}

Out of the total 1374 YES responses $31.1 \%$ accounted for "Virus Attack", 10.6\% accounted for "Trojan horse", 4.2\% accounted for "Spamming", 4.9\% accounted for "Phishing", $6.9 \%$ "Online frauds", $1.5 \%$ accounted for "Unauthorized accessing of your devices", $0.1 \%$ accounted for "Intellectual Property Rights violation", $0.7 \%$ accounted for "Email Scam / Email Spoofing", 2.3\% accounted for "Credit Card Frauds", $0.1 \%$ accounted for "Cyber Defamation", $0.5 \%$ accounted for "Software Piracy", $1.9 \%$ accounted for "Internet Time Theft", $0.9 \%$ accounted for "Computer Sabotage", $1.3 \%$ accounted for "Password Sniffing", $0.2 \%$ accounted for "Identity Theft", $0.1 \%$ accounted for "DOS/DDOS/Attacks", $0.7 \%$ accounted for "Pornographic Offences", 1.4\% accounted for "Cross Site Scripting", $0.5 \%$ accounted for "Salami Attacks/Salami Techniques", $\quad 0.7 \%$ accounted for "Cyberstalking/ Harassment", $1.9 \%$ accounted for "E-mail bombing/Mail bombs", $0.8 \%$ accounted for "Computer Network Intrusion", $0.7 \%$ accounted for "Shortened and Hidden Link", 19.0\% accounted for "Webjacking/Clickjacking/Pop-Up" and 7\% accounted for "Other" which includes enquiry of bank account details, enquiry of ATM details, keylogger installed at cyber cafe, mail about a lucky draw, document forgery. Hence it can be concluded that internet users mainly facing problems on Virus Attack and Webjacking/Clickjacking/ Pop-Up. From Q1 and Q2 it can be concluded that cyber security problems are exists in Pune.

\section{AWARENESS OF CYBERCRIMES}

Table 3: Unawareness on cyber security problems faced

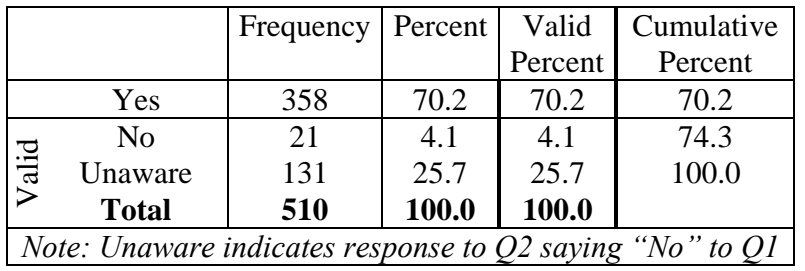

From table-1 it was observed that $29.8 \%$ respondents responds "No" to Q1 whereas from table-3 it can be seen that those who responds "No" to Q1 have also responded to Q2 with specific problem(s) instead of "Not Applicable". Means $25.7 \%$ respondents have responded to Q2 though they said they have not faced any cybersecurity problem. Which clearly indicates they are unaware of cybersecurity problems. Hence it can be concluded that internet users in Pune are unaware of various types of cybersecurity problems and more surprisingly they even unknown to the fact that they get victimized. 


\section{ANALYSIS OF CYBERCRIMES IN PUNE}

According National Crime Record Bureau, Pune is one of the fastest growing city with ample cybercrime cases registered under IT act and IPC ${ }^{11}$.

Analysis on cybercrimes is composed under following heads:

\section{Cybercrimes registered under IT Act}

- Cybercrimes by motive

- Cybercrimes by suspect

- Cybercrimes registered section wise

- Cybercrimes registered year wise

\section{Cybercrimes registered under IPC (with computers)}

- Cybercrimes by motive

- Cybercrimes by suspect

- Cybercrimes registered section wise

- Cybercrimes registered year wise

Facts highlighting the contribution or share of Pune towards cybercrime. Understanding escalation of cybercrimes in Pune city, the researcher chose to analyze the impact of cyber security by exploring various types of crimes under IT act and IPC in the period of 2002-2011. Though most of the incidences were unreported due to unawareness and other reasons like defamation.

\begin{tabular}{|c|c|c|c|c|c|c|c|c|c|c|}
\hline \multicolumn{11}{|c|}{$\begin{array}{l}\text { Table } 1 \text { : Cyber Crimes registered under various } \\
\text { incidences }\end{array}$} \\
\hline Year & ฮิ & ฮ્తి & ఫ્సิ & ્ֻণ & ఫ్ & હ્તิ & $\stackrel{\infty}{\stackrel{\overbrace{}}{ٍ ̆ 丶 ~}}$ & ڤ્సે & 을 & $\overline{\bar{\nu}}$ \\
\hline$\Xi \frac{\bar{u}}{4}$ & $\nabla$ & $\nabla$ & 0 & $a$ & 으 & \pm & $a$ & in & $\approx$ & $\infty$ \\
\hline 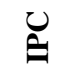 & 0 & 0 & 0 & 0 & - & 0 & 0 & $m$ & i & $=$ \\
\hline 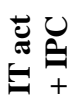 & $\nabla$ & $\nabla$ & 0 & $a$ & $=$ & \pm & $a$ & $\infty$ & $\infty$ & J \\
\hline 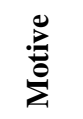 & 0 & $\nabla$ & 0 & $\sqrt{n}$ & $=$ & $\Xi$ & $a$ & $\infty$ & $\stackrel{\infty}{n}$ & 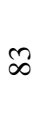 \\
\hline 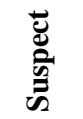 & 0 & $\nabla$ & 0 & $a$ & $=$ & $\Xi$ & $a$ & $\infty$ & $\stackrel{\infty}{n}$ & $\infty$ \\
\hline
\end{tabular}

\begin{tabular}{|c|c|c|c|c|c|c|c|}
\hline \multicolumn{7}{|c|}{ Table 2: Cybercrimes by Motive (Head wise) } \\
\hline \\
\hline
\end{tabular}

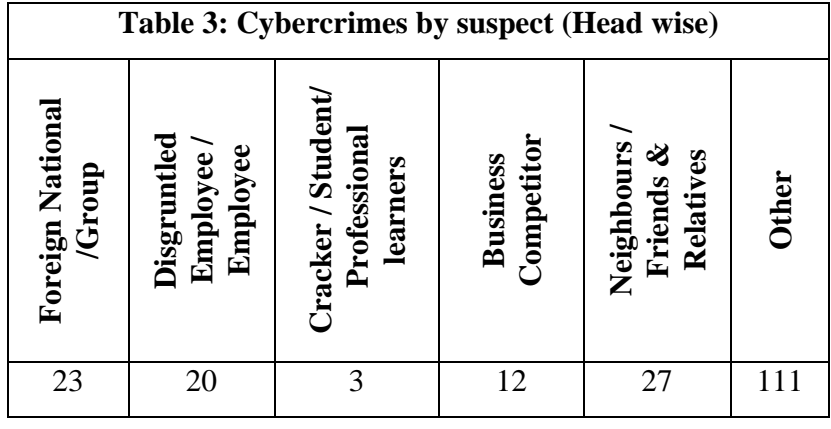

\begin{tabular}{|l|c|}
\hline \multicolumn{1}{|c|}{$\begin{array}{c}\text { Table 4: Incidences of cybercrimes/cases } \\
\text { registered under IT Act (Section wise) }\end{array}$} & Cases \\
\hline Tampering computer source documents (Sec. 65) & 5 \\
\hline $\begin{array}{l}\text { Hacking with computer system } \\
\text { i) Loss/damage to computer resource/utility } \\
\text { (Sec. 66)(1) }\end{array}$ & 54 \\
\hline ii) Hacking (Sec. 66)(2) & 10 \\
\hline $\begin{array}{l}\text { Obscene publication/transmission in electronic form } \\
\text { (Sec. 67) }\end{array}$ & 36 \\
\hline $\begin{array}{l}\text { Failure } \\
\text { i) Of compliance/orders of certifying authority } \\
\text { (Sec. 68) }\end{array}$ & 3 \\
\hline $\begin{array}{l}\text { ii) To assist in decrypting the information intercepted } \\
\text { by govt. agency (Sec. 69) }\end{array}$ & 1 \\
\hline $\begin{array}{l}\text { Un-authorised access/attempt to access to protected } \\
\text { computer system (Sec. 70)(9) }\end{array}$ & 0 \\
\hline $\begin{array}{l}\text { Obtaining licence or digital signature certificate by } \\
\text { misrepresentation/suppression of fact (Sec. 71)(10) }\end{array}$ & 0 \\
\hline Publishing false digital signature certificate (Sec. 73) & 0 \\
\hline Fraud digital signature certificate (Sec. 74) & 0 \\
\hline Breach of confidentiality/privacy (Sec. 72) & 4 \\
\hline Other & 59 \\
\hline
\end{tabular}

\begin{tabular}{|l|c|}
\hline \multicolumn{1}{|c|}{$\begin{array}{c}\text { Table 5: Incidences of cybercrimes/ } \\
\text { cases registered under IPC (Section wise) }\end{array}$} & Cases \\
\hline $\begin{array}{l}\text { Offences by/Against Public Servant } \\
\text { (Section 167, 172, 173, 175) }\end{array}$ & 2 \\
\hline $\begin{array}{l}\text { False electronic evidence } \\
\text { (Section 193) }\end{array}$ & 1 \\
\hline $\begin{array}{l}\text { Destruction of electronic evidence } \\
\text { (Section 204, 477) }\end{array}$ & 5 \\
\hline $\begin{array}{l}\text { Forgery (Section 463, 465, 466, 468, 469, 471, 474, } \\
\text { 476, 477A ) }\end{array}$ & 6 \\
\hline $\begin{array}{l}\text { Criminal Breach of Trust/Fraud } \\
\text { (Section 405, 406, 408, 409) }\end{array}$ & 27 \\
\hline $\begin{array}{l}\text { Counterfeiting } \\
\text { i) Property/mark } \\
\text { (Section 482, 183, 483, 484, 485) }\end{array}$ & 0 \\
\hline ii) Tampering (Section 489) & 0 \\
\hline iii) Currency/Stamps (Section 489A to 489E) & 0 \\
\hline
\end{tabular}

Source: Table 1-5: National Crimes Record Bureau (NCRB) 
Graph 1: Cybercrimes by Motive (Head wise)

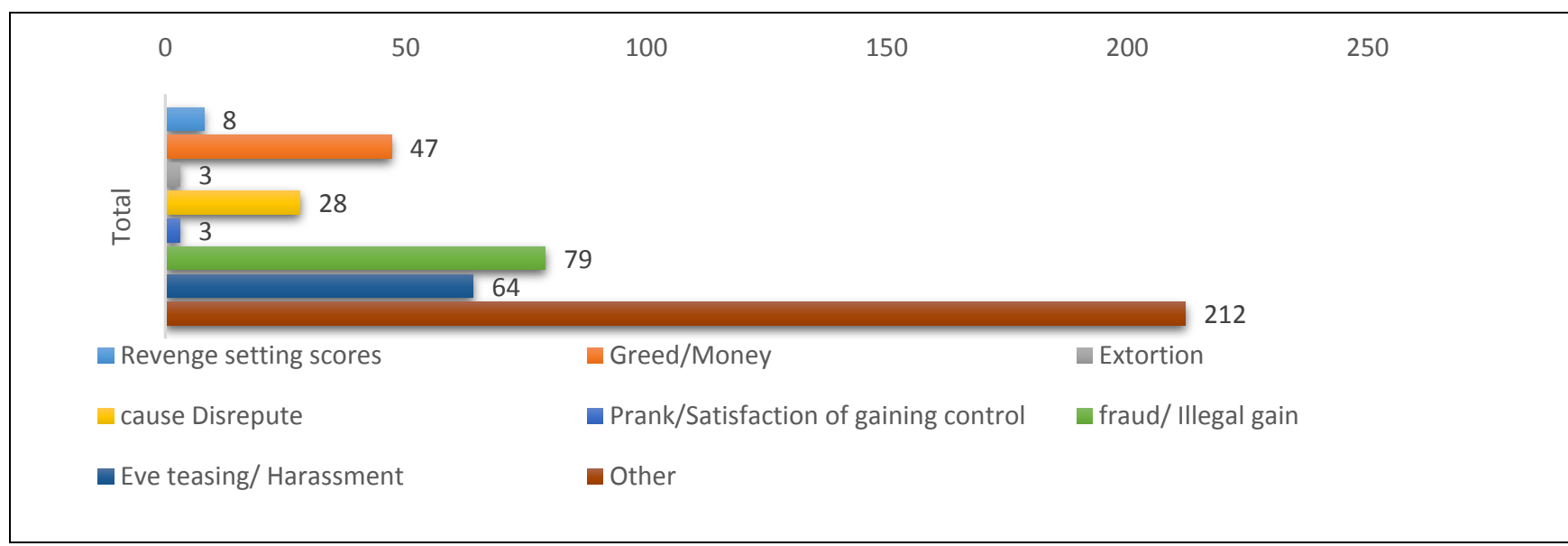

Source : Table 2

From the above graph it can be seen that cases registered by motive in Pune city under different heads were continuously increased. 444 cases registered under various heads in the last ten years 2002 to 2011. Most of the cases i.e. 212 were registered under the category "Other".

\section{Graph 2: Cybercrimes by motive (Year wise)}

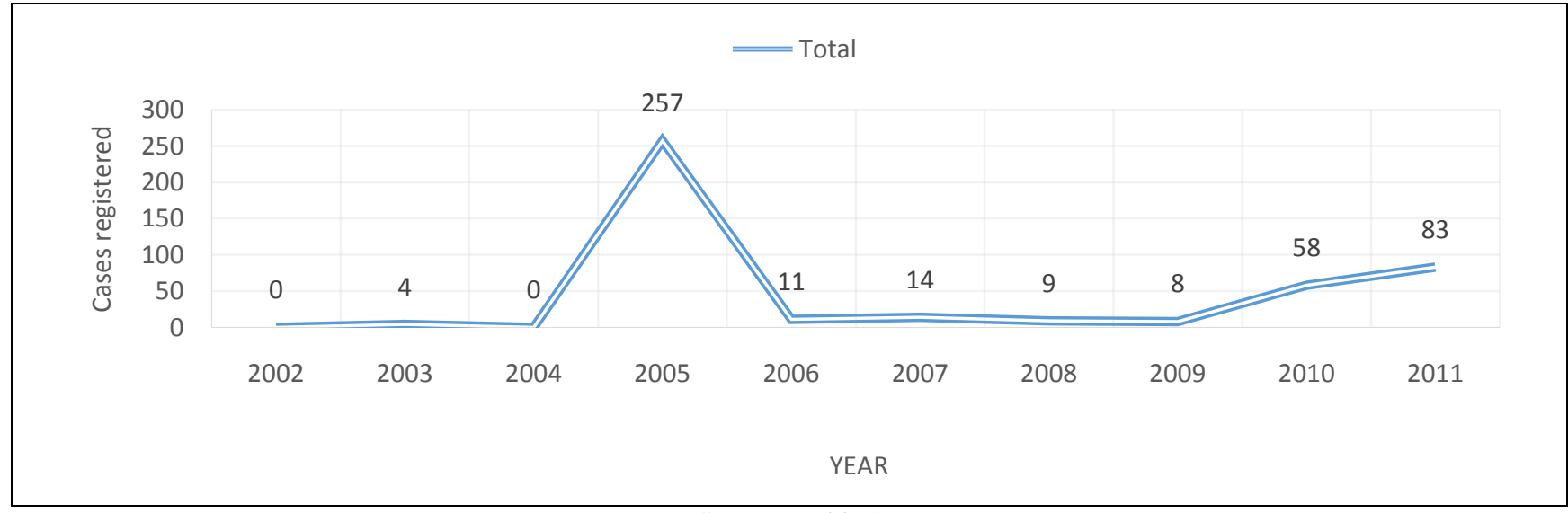

Source : Table 1

Above graph shows the year wise growth of crimes by motive in Pune city since 2002 to 2011 . Highest growth was observed in the year 2005 .
In last two years i.e. 2010 to 2011 growth rate was $43 \%$. Total 83 cases were registered in the year 2011. Which clearly shows the significant growth of cybercrimes in Pune city.

Graph 3: Cybercrimes by suspect (Head wise)

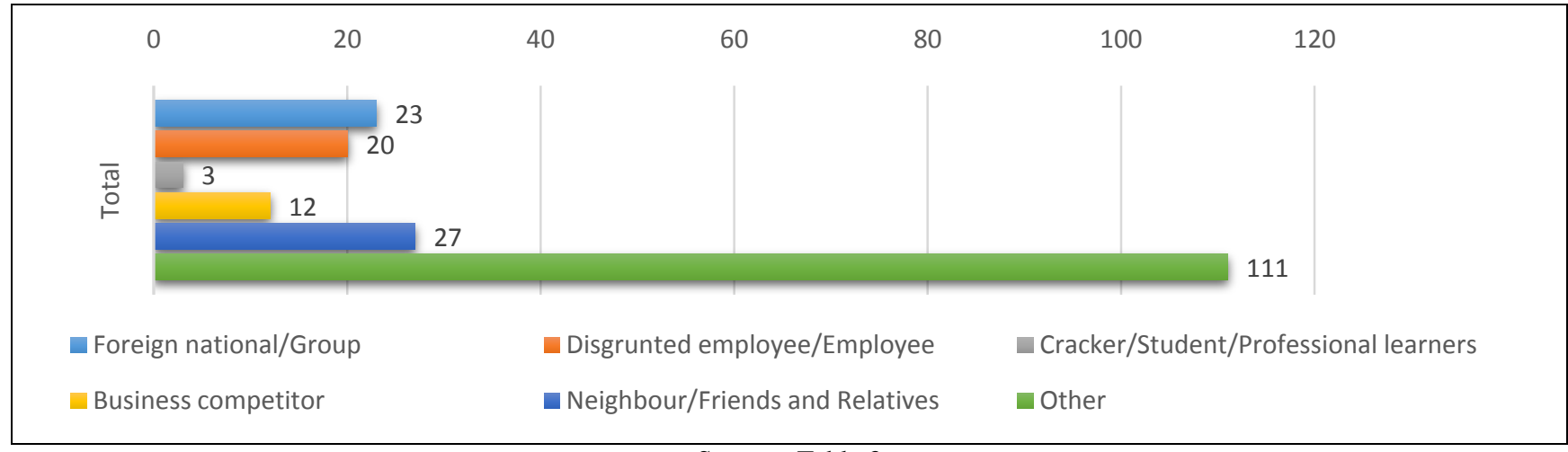

Source : Table 3 
Graph 3 shows that cybercrime cases registered by suspect in Pune city in last ten years (2002-2011). Cases registered under various categories were 196 .
Less number of cases were registered under the head "Cracker/Student/Professional learners" i.e. 3 whereas large number of cases were registered under the category "Other" i.e. 111 .

\section{Graph 4: Cybercrimes by suspect (Year wise)}

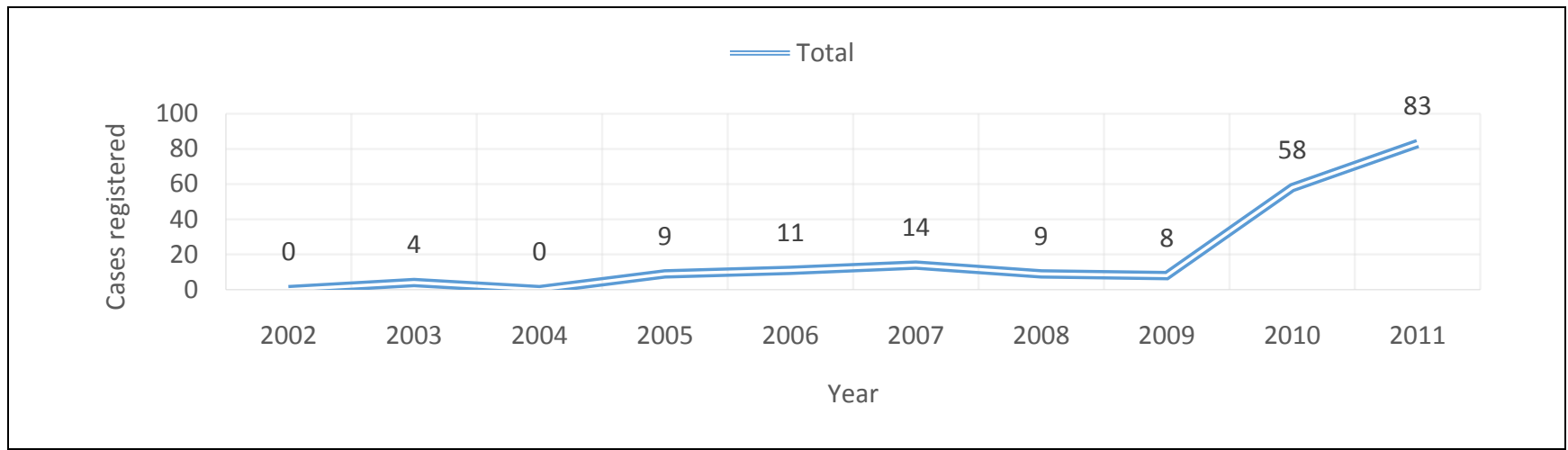

\section{Source : Table 1}

From the above graph it can be seen that out of 196 cases registered in last ten year from 2002 to 2011. Most of the cases (83) were registered in the year 2011. Compared to 2010 (58 cases).
Growth rate of $43 \%$ was observed in last two years which clearly indicates the significant growth of cybercrimes by suspect in Pune city.

\section{Graph 5: Incidences of cybercrimes/cases registered under IT Act (Section wise)}

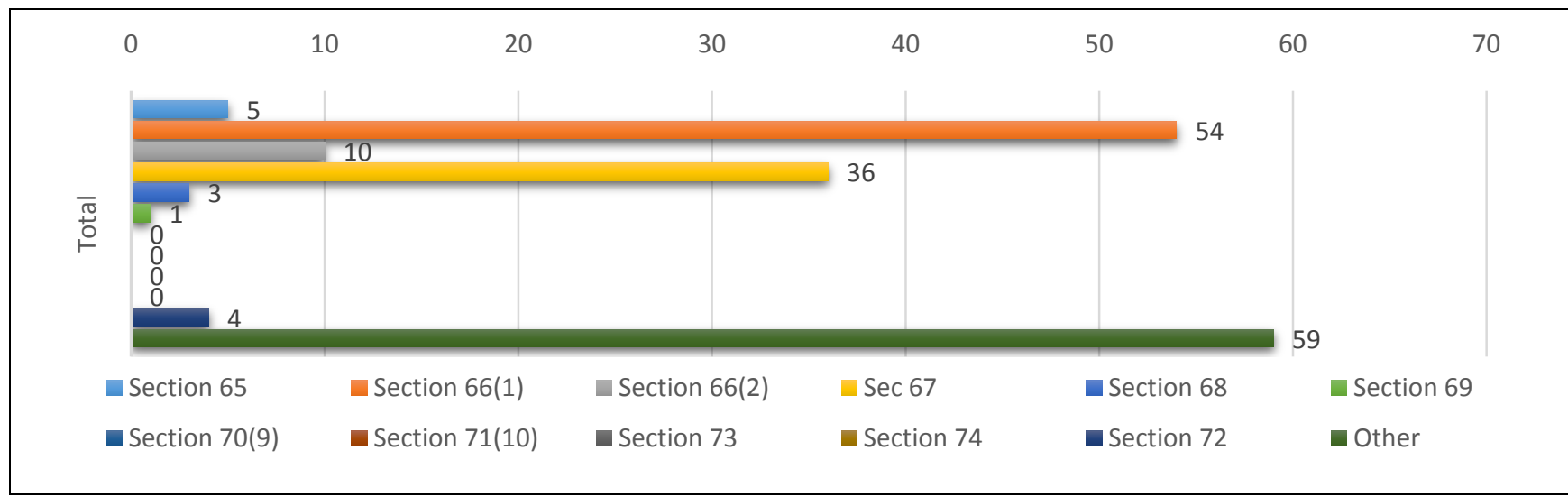

Source : Table 4

Above graph shows the incidences of cybercrimes/cases registered under IT act in Pune city since last 10 years from 2002 to 2011. Total 172 cases were registered under IT act with different sections.

Graph 6: Incidences of cybercrimes/cases registered under IT Act (Year wise)
Maximum 59 cases were registered under the head "Other" whereas 54 cases were registered under section 66(1) i.e.

"Loss/damage to computer resource/utility".

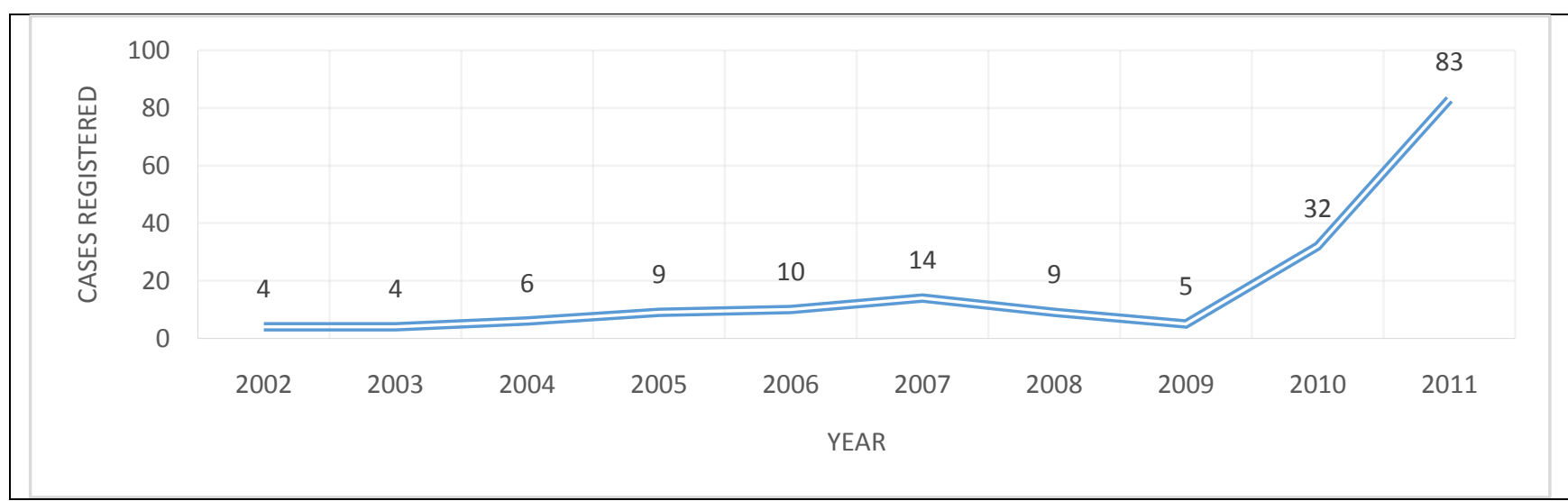


Above graph shows year wise incidences registered under IT act in Pune city. No cases were registered in the year 2002 whereas maximum 83 cases were registered in the year 2011.
Scenario shows the tremendous growth of $159 \%$ in last two years from 2010 to 2011 .

Graph 7: Incidences of cybercrimes/cases registered under IPC (Section wise)

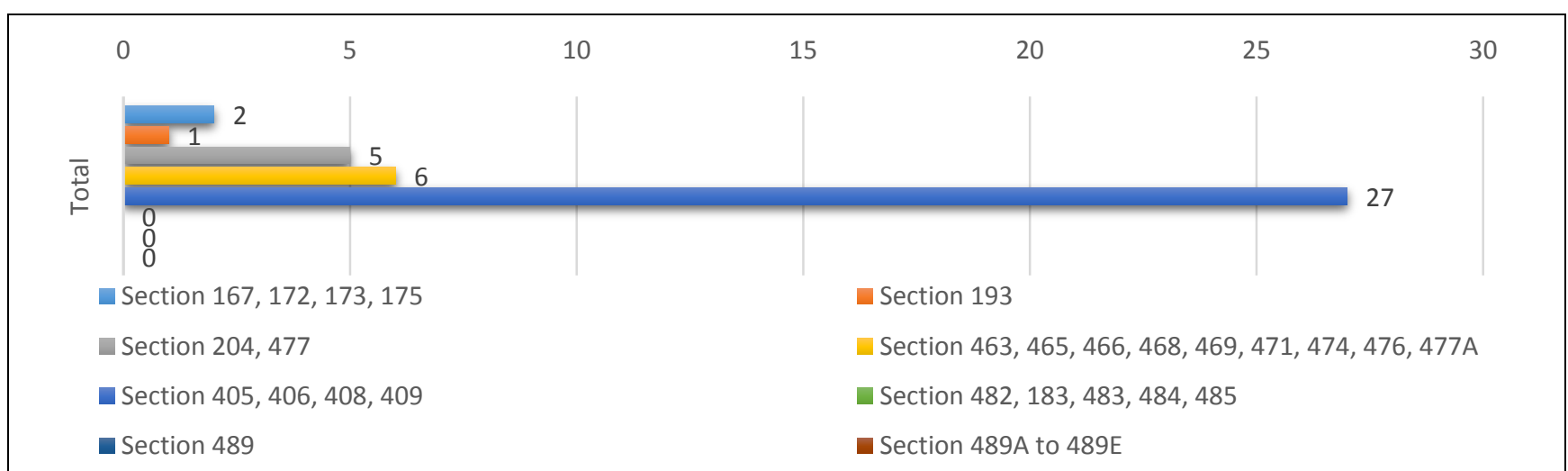

Source : Table 5

Above graph shows the number of cybercrimes/cases registered under various sections of IPC in Pune city. Total 41 cases were registered under IPC during last ten years. Most of the cases (27) were registered under the section 405, 406, 408, 409 i.e. "Criminal breach of trust/fraud".

\section{Graph 8: Incidences of cybercrimes/cases registered under IPC (Year wise)}

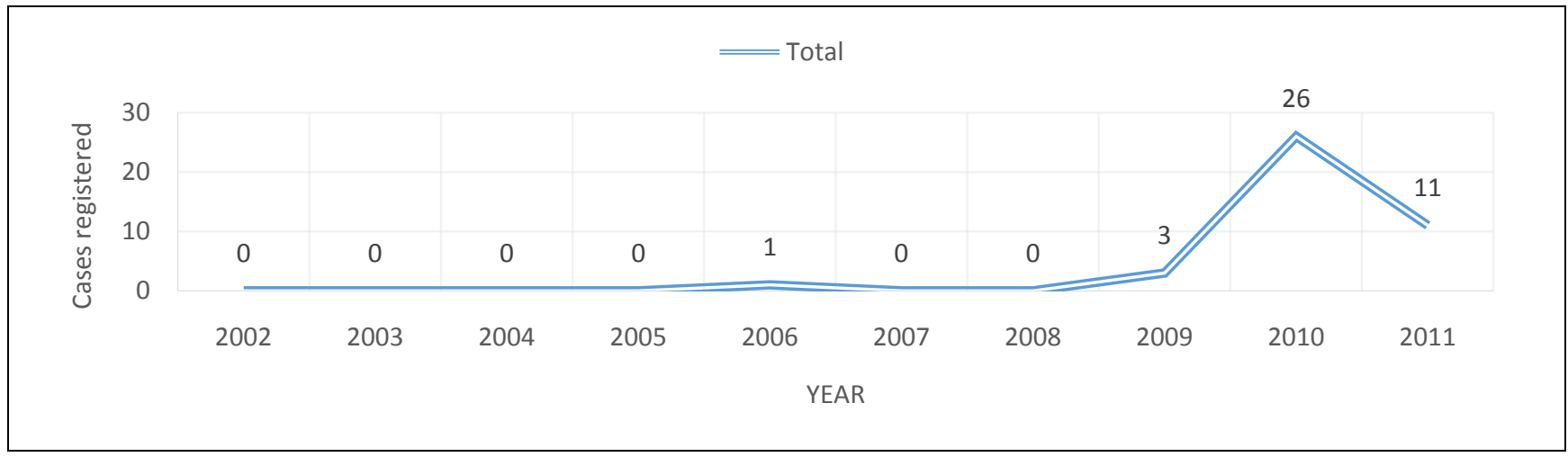

Source : Table 1

From the above graph it can be seen that in last ten years from 2002 to 2011 number of incidences were registered under IPC. Large number cases (26) were reported in the year 2010 whereas only 11 cases reported in the year 2011 which shows that the growth rate was decreased by $58 \%$.
At the same time it is important to take the count of total number of cases registered under IT act as well as IPC as the impact of cybercrimes is not analyzed solely on the basis of incidences registered under IT act or IPC.

Graph 9: Total cybercrime cases registered under IT Act and IPC

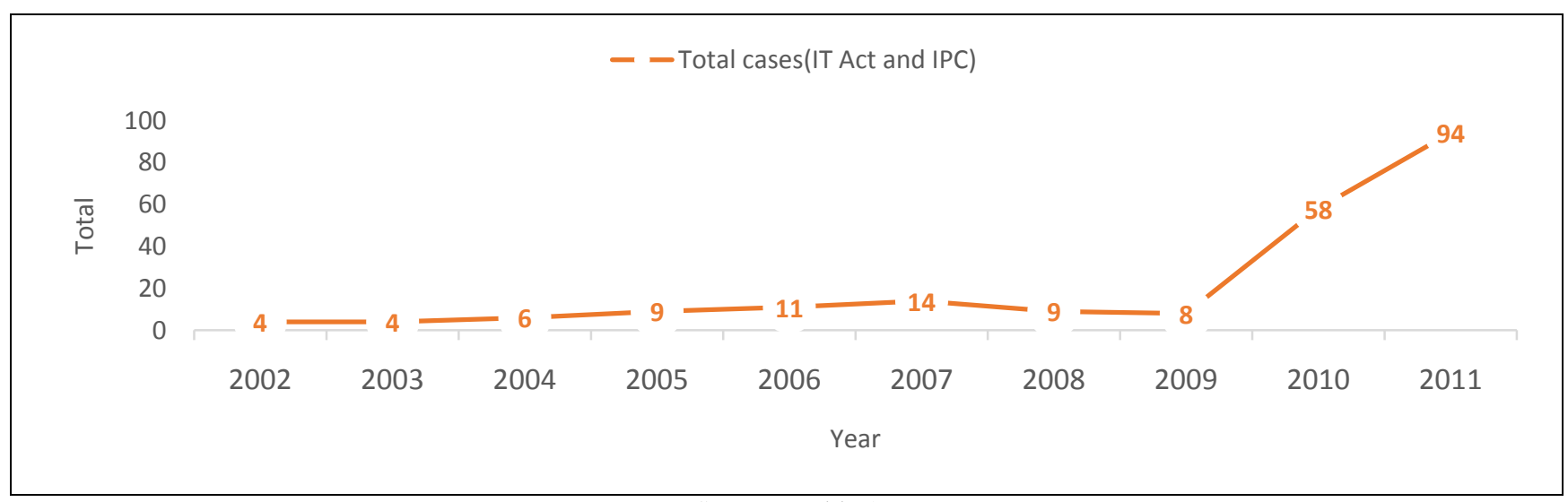

Source : Table 1 
Above graph shows the total number of cases registered under both IT act and IPC in Pune city. In the year 2002 and 2003, 4 cases were registered, 6 cases registered in the year 2004, 9 cases registered in 2005, 11 cases registered in 2006, 14 cases registered in 2007, 9 cases registered in 2008, 58 cases registered in 2010 whereas 94 cases were registered in the year 2011. Scenario shows the significant growth of $62 \%$ from the year 2010 to 2011 towards reporting the cybercrimes

\section{CONCLUSION}

Cybercrimes are varying in its nature due to enhancement in technologies. Due to diversified nature it is difficult to identify the cybersecurity problems which leads to unawareness on security issues. The proliferation in registering the cybercrimes under various sections of IT act and IPC shows the severity of such cyber threats however most of the cases were still unreported because of various reasons. Considering this scenario security and awareness training model towards public security will be developed in preliminary phase. In next phase of the research a tool will be designed with the implementation of multilayer security algorithm.

\section{REFERENCES}

[1] Nagpal, R. 2008, Evolutions of Cybercrimes, Asian School of Cyber laws, p. 2.

[2] Cybercrime, available at http://www.britannica.com. (n.d.). Retrieved March 05, 2012 at 7.48 pm.
[3] Barkha, Rama Mohan, U. 2011, Cyber Law and Crimes, IT Act 2000 \& Computer Crime analysis. (3rd ed.), ISBN: 978-93-81113-23-3, p. 7.

[4] Muthukumaran, B. 2008, Cybercrime scenario in India, criminal investigation department review, Chief Consultant, Gemini Communication Ltd., p. 17.

[5] "Cybercrime system requirements in India: Most necessary thing in India, available at

http://www.cyberlawsindia.net/requires.html" (n.d.). Retrieved May 13, 2012 at 9.30 am.

[6] Srivastava, B., Abhichandani, T., Biswas, A., Thakare, M. 2011, Report on Internet in India (I-Cube), Internet \& Mobile Association of India (IAMAI), p. 3.

[7] Krejcie, R.V., \& Morgan, D.W. 1970. Determining Sample Size for Research Activities. Educational and Psychological Measurement.

[8] Hunt, N., Tyrrell, S. 2001. Stratified Sampling

[9] Cybercrime classification, available http://shodhganga.inflibnet.ac.in/bitstream/10603/7829/1 2/12_chapter\%203.pdf

[10] Godbole, N., Belapure, S. 2011, Cyber Security, Understanding Cybercrimes, Computer Forensics and Legal Perspectives, Wiley India Pvt. Ltd., (1st ed.), ISBN: 978-81-265-2179-1

[11] Incidence of Cases Registered under Cyber Crimes in States/UTs, http://www.ncrb.org. (n.d.). Retrieved June 10,2014 at $9.40 \mathrm{pm}$ 